\title{
Post-Investment Contributions of Business Angels from the Investee Perspective in Turkey
}

\author{
Mustafa Halid Karaarslan ${ }^{1}$, Y1lmaz Bayar ${ }^{2}$ \& Cahid Özdeveci ${ }^{1}$ \\ ${ }^{1}$ Department of International Business, Faculty of Business, Karabuk University, Karabuk, Turkey \\ 2 Department of Economics, Faculty of Economic and Administrative Sciences, Usak University, Usak, Turkey \\ Correspondence: Mustafa Halid Karaarslan, Department of International Business, Faculty of Business, Karabuk \\ University, Karabuk, Turkey. Tel: 90-370-433-8262/2578.
}

Received: March 31, 2016

Accepted: April 11, 2016

Online Published: April 22, 2016

doi:10.5430/ijba.v7n3p44

URL: http://dx.doi.org/10.5430/ijba.v7n3p44

\begin{abstract}
Business angels are one of the crucial financing opportunities for the companies in early phases of development. This study examines the contributions of the business angels to the investees in the areas of management, marketing and financing and accounting during the post-investment process by interviewing with the entrepreneurs who took financial support from the business angels in establishment phases of their companies by using in-depth face-to-face interviews and telephone interviews from the perspectives of the investee companies. We found that the business angels made significant contributions especially in the fields of human resources management, networking, marketing and financing during post investment period.
\end{abstract}

Keywords: business angels, post-investment involvement

\section{Introduction}

Business angels are becoming critical provider of funding at seed and early phases of company development which generally do not have access to the traditional fund sources (Harrison and Mason, 2010:vii). Angel investing has had a long past in the world, but it became familiar in 2000s years in Turkey. Angel investing has been emerged in Turkey through business angel networks pioneered by national universities and increasing value of e-ventures. However, there was no formal statistics about angel investing in Turkey until 2012. Turkish government formalized the activities angel investments in Turkey by enacting "The Code numbered 6327 Amending the Individual Pension Savings and Investment System Law and Certain Laws and Statutory Decrees" on 13 June 2012. In this regard Under Secretariat of Treasury prepared a regulation on the angel investments considering this law and begins to issue regular reports on the angel investing. The first business angel network (BAN) was established by Middle East Technical University (METU) in Turkey in 2007 (METUTECHBAN, 2016). There have been 348 business angels in 13 accredited BANs in Turkey (Under Secretariat of Treasury, 2016: 17-29). 11 BANs are generally located in Istanbul, only one is located in İzmir, and one is located in Ankara.

Nearly no direct studies have been conducted on the post-investment contributions of business angels on ventures from the perspective of entrepreneurs in Turkey. We found that only Karabayır et al. (2012) conducted a study from the business angel perspective. So this study will be a pioneering study on the post-investment contributions of business angels in Turkey. The objective of the study is to elicit the contributions of the business angels after angel investing from the perspectives of entrepreneurs. The study is organized as follows. Section 2 overviews the literature on the value added to the investees by the business angels during post-investment process and Section 3 presents research design, interview findings and discussion and finally our study is over with the conclusion.

\section{Literature Review}

The business angels have been investigated from the investor's and entrepreneur's perspective and the public policy and capital market perspectives (Zachary and Mishra, 2013; 260). However, empirical studies have generally focused on the financial contributions of the business angels and disregarded the non-financial contributions of the business angels to the investee ventures. But the number of empirical studies on the non-financial contributions of the business angels has been begun to increase in recent times. Politis (2008) summarized the contributions of business angels in his study. We investigated the post-investment contributions of business angels under the main areas presented in Table 1 considering Politis (2008) and late empirical studies. 
Table 1. Summary of contributions of business angels to the ventures

\begin{tabular}{ll}
\hline Main areas & Sub-functions \\
\hline Management & advice \& counselling in general management Mason and Harrison (1996), \\
& Tashiro (1999) \\
& serving as sounding board Stevenson and Coveney (1996) \\
& development of business strategies and products Harrison and Mason (1992), \\
& Ehrlich et al. (1994), Amatucci et al. (2002), Brettel (2003) \\
& enhancing management skills Paul et al. (2003) \\
& networking Mason and Harrison (1996), Lumme et a. (1998), Brettel (2003), \\
& Sætre (2003), Sørheim (2005) \\
\hline Networking & sharing their networks with the entrepreneurs (Macht and Robinson (2009) \\
\hline Marketing \& advertising & development of marketing plans Harrison and Mason (1992) \\
& advice \& counselling in marketing Mason and Harrison (1996), Tashiro (1999) \\
\hline Accounting \& finance & advice \& counselling in accounting and finance Mason and Harrison (1996), \\
& Tashiro (1999) \\
& monitoring and evaluating financial performance Ehrlich et al. (1994) \\
& helping access to additional finance Paul et al. (2003), Amatucci and Sohl (2004), \\
& Macht and Robinson (2009) \\
\hline Production & advice \& counselling in operational activities Tashiro (1999), Amatucci and Sohl \\
& (2004) \\
industry knowledge, resourcing new dynamic business structures Lumme et \\
al.(1998)
\end{tabular}

\section{Research Design, Interview Findings and Discussion}

\subsection{Research Design}

We investigated the financial and non-financial contributions of the business angels to the investee companies in Turkey considering the empirical studies in the literature. In this regard, we used in-depth face-to-face interviews and telephone interviews from the perspectives of the investee companies for the data collection during the period May-June 2015 and benefited from a semi-structured form in the appendix. We concluded that qualitative research was the most appropriate method for our study, because there have been limited number of entrepreneurs getting angel investing. We reached the participants from the web sites of business angel network (BAN)s and also tried to contact with each BAN by e-mail and phone, then we contacted with the entrepreneurs. Consequently we had an interview with ten entrepreneurs, contacted with seven entrepreneurs by face-to-face interviews and three entrepreneurs by internet video conferencing and the interviews took 40 minutes on average. We used the codes of I1, I2, I3, I4, I5, I6, I7, I8, I9 and I10 to express the views of the entrepreneurs which got angel investing in the study.

The first constraint of the study was related to the sampling method. We preferred to reach the entrepreneurs through the websites of BANs, but most of the BANS were unwilling to cooperate with us or partly share their investments with us. In this case, our sample was probably consisted of the entrepreneurs having better relations with angel investors. So our sample of entrepreneurs may achieve on average. The second constraint was that we could not verify that statements of the entrepreneurs were true or not, because they simultaneously got multiple angel investments. On the other hand business angels also supported multiple investments simultaneously.

\subsection{Interview Findings and Discussion}

The summary of the interviews were presented in Table 2. The ages of entrepreneurs that we interviewed with were between 21 and 41 years and their work experiences also changed between 1 and 25 years. Our sample completely consisted of men entrepreneurs. No women entrepreneur accepted our interview proposal, although we got a for effort. Two of the entrepreneurs had $\mathrm{PhD}$ degree, four had master degree and four had bachelor degree. Nine of the businesses were established in Istanbul, one was established in Ankara. Two of the businesses provide on line services, two ones provide mobile services, the others provide digital health, e-trade, translation services, private 
security services and products integrated with mobile technology. The number of employees in the businesses varied between 6 and 90 persons and the number of founders changed between 1 and 5 persons. On the other hand the entrepreneurs simultaneously got investments between 1 and 19 business angels. The businesses in our sample have operated between 1 and 11 years. Only two ventures got angel investing at the establishment phase, the remaining ones got angel investing at growth stage and the share of business angels in the businesses was at least $15 \%$, but it changed. However, none of the business angels have had majority vote. Half of the business angels were on the board. The meeting frequency of the entrepreneurs with the business angels also changed between every day and once a year and they talked with the business angels about future goals, financial conditions and problems.

Table 2. Summary of interview

\begin{tabular}{|c|c|c|c|c|c|c|c|c|c|c|}
\hline & Age & Gender & Education & $\begin{array}{l}\text { Business } \\
\text { experience }\end{array}$ & $\begin{array}{l}\text { Business } \\
\text { segment }\end{array}$ & $\begin{array}{l}\text { Number } \\
\text { of } \\
\text { employees }\end{array}$ & $\begin{array}{l}\text { Number } \\
\text { of } \\
\text { business } \\
\text { partner } \\
\text { (except } \\
\text { business } \\
\text { angel) }\end{array}$ & $\begin{array}{l}\text { Number } \\
\text { of } \\
\text { business } \\
\text { angels }\end{array}$ & $\begin{array}{l}\text { Establishment } \\
\text { date }\end{array}$ & $\begin{array}{l}\text { Date of the } \\
\text { partnership } \\
\text { with the } \\
\text { business } \\
\text { angel }\end{array}$ \\
\hline I1 & 37 & Male & $\mathrm{PhD}$ & 25 & $\begin{array}{l}\text { Private } \\
\text { security } \\
\text { services }\end{array}$ & 25 & 2 & 4 & 2007 & 2011 \\
\hline $\mathrm{I} 2$ & 26 & Male & Bachelor & 1 & $\begin{array}{l}\text { Mobile } \\
\text { services }\end{array}$ & 40 & 3 & 2 & 2013 & 2013 \\
\hline I3 & 35 & Male & MA & 10 & E-trade & 36 & 5 & 10 & 2013 & 2013 \\
\hline I4 & 25 & Male & Bachelor & 3 & $\begin{array}{l}\text { Products } \\
\text { integrated } \\
\text { with mobile } \\
\text { services }\end{array}$ & 13 & 4 & 8 & 2013 & 2014 \\
\hline I5 & 25 & Male & Bachelor & 2 & $\begin{array}{l}\text { Translation } \\
\text { service }\end{array}$ & 6 & 3 & 19 & 2013 & 2015 \\
\hline I6 & 41 & Male & MA & 13 & $\begin{array}{l}\text { Digital } \\
\text { health } \\
\text { services }\end{array}$ & 32 & 1 & 10 & 2004 & 2008 \\
\hline I7 & 40 & Male & MA & 20 & Organization & 90 & 4 & 1 & 2007 & 2013 \\
\hline I8 & 26 & Male & MA & 4 & $\begin{array}{l}\text { Online } \\
\text { services }\end{array}$ & $\begin{array}{l}3 \text { full time } \\
\text { employee } \\
\text { and } 4 \text { part } \\
\text { time } \\
\text { employee }\end{array}$ & 4 & 11 & 2013 & 2014 \\
\hline I9 & 36 & Male & $\mathrm{PhD}$ & 14 & $\begin{array}{l}\text { Online } \\
\text { services }\end{array}$ & 12 & 2 & 19 & 2009 & 2009-2011 \\
\hline $\mathrm{I} 10$ & 39 & Male & Bachelor & 22 & $\begin{array}{l}\text { Mobile } \\
\text { services }\end{array}$ & 7 & 1 & 1 & 2011 & 2013 \\
\hline
\end{tabular}


Table 2. Summary of interview (continue)

\begin{tabular}{|c|c|c|c|c|c|c|c|}
\hline $\begin{array}{l}\text { Site of } \\
\text { establishment }\end{array}$ & $\begin{array}{l}\text { The stage of first } \\
\text { angel } \\
\text { investment }\end{array}$ & $\begin{array}{l}\text { Share of } \\
\text { business } \\
\text { angel in the } \\
\text { enterprise } \\
(\%)\end{array}$ & $\begin{array}{l}\text { Does the } \\
\text { business } \\
\text { angel have } \\
\text { majority } \\
\text { vote? }\end{array}$ & $\begin{array}{l}\text { Are } \\
\text { business } \\
\text { angels in } \\
\text { the board of } \\
\text { directors? }\end{array}$ & $\begin{array}{l}\text { Do the } \\
\text { business } \\
\text { angels have } \\
\text { any } \\
\text { privileges? }\end{array}$ & $\begin{array}{l}\text { Frequency } \\
\text { of meeting } \\
\text { with the } \\
\text { business } \\
\text { angel }\end{array}$ & $\begin{array}{l}\text { Interview } \\
\text { issues } \\
\text { the busi } \\
\text { angels }\end{array}$ \\
\hline
\end{tabular}

\begin{tabular}{|c|c|c|c|c|c|c|c|c|}
\hline I1 & Ankara & Pre-production & 15 & No & Yes & Yes & $\begin{array}{ll}\text { At least } & 2 \\
\text { times } & \text { a } \\
\text { month } & \end{array}$ & $\begin{array}{l}\text { Potential } \\
\text { businesses } \\
\text { and emerging } \\
\text { products }\end{array}$ \\
\hline $\mathrm{I} 2$ & İstanbul & $\begin{array}{l}\text { Establishment } \\
\text { phase }\end{array}$ & 25 & No & No & No & Changing & Strategy \\
\hline I3 & İstanbul & $\begin{array}{l}\text { Establishment } \\
\text { phase }\end{array}$ & $\begin{array}{l}\text { more than } \\
50 \%\end{array}$ & No & Yes & No & $\begin{array}{l}1 \text { time a } \\
\text { month }\end{array}$ & $\begin{array}{l}\text { Performance } \\
\text { evaluation }\end{array}$ \\
\hline I4 & İstanbul & Growth stage & 22 & No & No & No & Changing & - \\
\hline I5 & İstanbul & Growth stage & 18 & No & Yes & Yes & $\begin{array}{l}1 \text { time a } \\
\text { week }\end{array}$ & Sales \\
\hline I6 & İstanbul & Growth stage & 50 & No & No & No & Every time & - \\
\hline I7 & İstanbul & Growth stage & 21 & No & No & No & $\begin{array}{l}1 \text { time a } \\
\text { year }\end{array}$ & Vision \\
\hline I8 & İstanbul & Growth stage & 20 & No & Yes & $\begin{array}{l}\text { Not } \\
\text { available }\end{array}$ & $\begin{array}{l}1 \text { or } 2 \text { times } \\
\text { a month }\end{array}$ & $\begin{array}{l}\text { Goal revision } \\
\text { and problems }\end{array}$ \\
\hline I9 & İstanbul & Growth stage & 49 & No & Yes & No & $\begin{array}{l}2 \text { or } 3 \text { times } \\
\text { a month }\end{array}$ & $\begin{array}{l}\text { Financial plan } \\
\text { and future } \\
\text { planning }\end{array}$ \\
\hline $\mathrm{I} 10$ & İstanbul & Growth stage & 20 & No & $\begin{array}{l}\text { Not } \\
\text { available }\end{array}$ & Yes & Changing & Problems \\
\hline
\end{tabular}

\subsubsection{Contribution of the Business Angels at the Field of Management}

The entrepreneurs told us that business angels contributed to their ventures in the areas of human resources, experience sharing, monitoring the venture, institutionalization and realization of business ideas. Moreover, they contributed to the decision-making process of the ventures, formation of organization and development of managerial skills.

The contributions of business angels at the establishment of business model can be evaluated at two different categories. The first group of entrepreneurs is the ones who get angel investments after they begin to make money. This group of entrepreneurs needs no contributions from the business angels at the establishment of business angels, because they currently have business models, but business angels still make contribution to their business models depending on the present conditions. The second group of entrepreneurs is the ones who get angel investments before realization of business ideas or they already have begun to operate but they need restoration about their business models for grow-up.

I10: “... We are looking at the sources, already there are sources related to the business model in the literature. We are looking at them how the business model should be."

15: "They do not take part in the business model too much. Because they trust the entrepreneur."

I8: “... we had no contributions about business idea. We ourselves developed it...We made this completely..."

I9: “...improvement may be done and you can always get contribution on that topic, it is a separate issue. But it is not like you, when there is nothing visible. Only the man who established the firm may do it."

I1: “...Their plans are preparing and we conducted the studies about these plans... Board meetings were 
conducted. The business angels wanted to learn what you really did. Your business model constantly changes before you know it. We see that we proceed too much, although the business angels say nothing."

I3: “....as long as we talked and we made some evaluations together with our team, some issues became clearer. In this respect, I could say that the business angel made serious contributions."

I4: “....our business angels said that what we could do at business model, that is to say how we could sell this, shall we rent or sell... At this point, they helped us."

I1: “...We reached a point by working with business angels on clearing of the way we drew... We did nothing and focused only what we could do through our expertness in 5-6 months after getting angel investment. These ideas surfaced after this process."

The major contributions of business angels at the field of management were establishment of firm organizational structure, determination of duties and responsibilities within the firm and determination of control and supervision procedures of the firm. Also the entrepreneurs who got less contribution in the field of management were generally experienced persons or persons with experienced partners.

I2: “...We were checking some decisions with business angels, we got their ideas, but we absolutely managed the firm."

I1: “...They pressurized a little... You were a firm like Swiss army knife... One person undertook 6-7 roles... The customers generally did not like this kind of firm. Now were converging a firm which was extreme luxurious and affected the sighted. The contributions of the business angels were quite a few..."

I4: “...They support us about some issues such as how an organizational structure should be or how chiefs should behave towards employees, because they were from an institutional life ..."

I3: "Business angels, who run a similar company which is 5-10 times larger than your firm...may reflect their accumulation of knowledge to you. In other words, maybe otherwise you run your business headlong. Oh sales are good, go on. We recruited new staff, everything is fine, but when you are engaged in work and look at the data a little more in detail (from sales to cost, staff performance at work, from operation to purchase, and from marketing to IT in each department with detailed key performance indicator), it requires serious expertise... It may not be too easy to discover the firm in 3-5-6 months after establishment of firm. At this point ... how this work is run? And which data should be considered in conducting the firm. In other words why does the business really shape up? Is it right to say that the business shapes up by looking at two data or looking more detailed things reveals that the things going right may not go right in fact or quite the contrary the things going bad may go good in fact?

If you are a start-up, there is a steering wheel in front of you, but there are virtually no indicators. You begin to form those indicators gradually. You look at sales indicator, profit-loss indicator, number of users, number of website visitors. You look at how many of the visits turning to customs, the sources of customer traffic and their costs. These begin to develop and be complicated gradually. At the end of the day you find yourself in front of a cockpit which includes hundreds of data and parameters... We should steer to which side by looking at which parameter, should we step on the gas more or release the gas pedal a little, should we enlarge our team or make investments in the system, or focus to expand the firm by concentrating on marketing, while running the firm... It is waste of time to follow an unnecessary parameter and try to infer from it. Also it may mislead you. Therefore, it may be more efficient to decide which data should be monitored and which key performance indicator is more valuable for you together with experienced people.

Business angels also contributed to the human resources management in the diverse areas such as determination of personnel positions in the firm, preparation and announcement of job advertisements, personnel selection, forwarding the talented personnel to the firm, determination of facilities for the personnel and regulation of communication between labor and management. Thus the entrepreneurs employ better personnel and benefit from personnel better.

I1: "They define the missing roles in the firm ... Some roles are professional and we transferred staff and partners from world giants... These transfers accelerated the firm 3-4 times more like skyrocket."

I3: "There are some abilities around. Some may split with the firm and the business angels inform us about this kind of event... We sometimes received consultancy from some invaluable persons the business angels directed us from their own firms... Sometime you cannot be sure of somebody and you may request that you can see this person. At that time they also interview with that person... That kind of passing happens."

I7: "We transferred an extra-smooth friend....This person has very good experience and is from the 
environment which I could not meet... That person contributed to our firm very much."

I2: "...The business angels direct us the right persons, when there are very clever, diligent and enthusiastic people in the market..."

I4: “...They helped us how we establish a dialog with our employees and we should not employ relatives or acquaintance as an employee... They sometimes informed us about staff recruiting into open position or about we pay attention to during an interview."

I6: "We talked with the business angels about nearly everything from job advertisements to criteria related to the staff recruiting."

I5: "They can share our job advertisement through their own channels and social network... They supported us too much especially about recruitment and law. What we should pay attention to ... They shared all the contracts with us. It was priceless for us."

I8: “...They can announce the job advertisement for us. In fact, we found all the trainees in our team through those advertisements."

I9: “... There were perhaps tens of persons, perhaps hundreds of persons around all them which have worked with them until that day. Therefore, they can give more concrete and useful ideas to us about what we do about human resources management... We can ask their advice about nearly everything from wages to the responsibilities."

I10: "The business angel transferred a director of human resources from a good firm...Director supported us about new staff recruiting, happiness of existing personnel and their compensation policies."

We found that the business angels generally monitor the financial data to follow and evaluate the firm performance and give suggestions. On the other hand the entrepreneurs prepare detailed reports at regular intervals. Thus the entrepreneurs get feedback from the business angels as a result of these reports. The business angels did not intervene in the work, because their investment amount was not too high, but they began to intervene in management more after making large angel investments in further stages of company development.

I6: "...They are only in a position of observer and advising."

I3: "They give suggestions more. We present them monthly reports."

I7: “...We are sending monthly reports about this month's revenue and innovations etc. This is something we agreed on but not obligatory... There is no situation or intervention like if only you did this way."

I4: “...We have to receive their approvals for the works requiring very high amount of money. We talked about the fiscal position of the previous month at every month only for information purposes."

I5: “...We are sending a very detailed report at the end of every month ... We are sharing everything including the figures related to the all operational transactions and these are controlled at every month... They give suggestions depending on the figures."

I2: "A fiduciary relationship. Everything is clear... We share all the information with our business angels transiently."

I9: “...You are reporting... You are also checking yourself when giving report... preparing those analyses...Also you unavoidably begin to think as if you are business angel... This is in the middle of consultancy and supervision."

I5: “...Now we are going good... Unfortunately they intervened in two ventures which the work was going bad ... The business angel heads the company, if the work goes bad. The entrepreneur heads the company, if the work goes right."

I10: "We were sending situation report at every month. He employed one manager... The manager did that and saw the risky sides."

I1: "Business angel should be observer. Supervision and control begins after getting high angel."

\subsubsection{Contribution of the Business Angels at the Field of Networking}

Networking is one of the fields which the entrepreneurs received maximum benefit from business angels. All the entrepreneurs except one benefited from the networks of the business angels. The entrepreneurs may contact with persons whom the business angels recognized through having good time together or by way of the business angels. Sometimes the entrepreneurs may want the business angels to introduce customers, successful persons in that field or the persons contributing their own job to them. The contribution of business angels for international connections was 
relatively more limited. However two entrepreneurs stated that they did not benefit from the networks of business angels much, even one said that business angel made friends by means of him.

I8: “...Is there any start-up, which could have achieved in our job, we know? ... I asked for them to meet me with the firms which can give suggestions at first hand, not via customers... They were on the point which we are on now and did certain things... and reached a good point... we also want to reach that point... How you make sales? How you make online advertisements? How many people your team consists of? How many software developers you have? How many salespersons you have... We should understand their internal dynamics and try to apply in our firm ..."

I3: "Firstly I thought that network should above capability set... Otherwise having extensive networks does not mean a thing. If you have right endowment, then the value of networking increases significantly and leads multiplier effect... If you enter this kind of business angel network, you find the chance to meet a man who brings famous brands to Turkey because those persons are interrelated too much... We were met many people from lawyers, interior architects, managers of large furniture firms to the managers of the 50 times larger firms than our firm which do similar things abroad. It was very valuable for us."

I8: “...We are searching for customers. We ask for the business angels whether they have connections in some large leading firms as long as we are searching for customers. If they have, we want an introduction mail from them."

I5: “... They can arrange meetings. They can provide convenience for us, if we conduct advertising activities in any place... They can easily open the doors which we have problems in opening... They are mainly sending sales mails. We are writing our target firms weekly... The person having connections in those firms takes responsibility and is sending mails."

I3: "There are generally persons we do not know... The business angel tells us that you had better become acquainted with this person. Sometimes we demand to meet with somebody through the business angel. They like that they have us meet with the people who they feel that they are useful for us. Thus we are meeting with many domestic and foreign people. Panel and conferences about entrepreneurship are organized weekly, the entrepreneurs should spend $5 \%$ of their times and focus on their work during the rest of time. The dosage of networking also should be set well. You have thousands of business cards, but most of them means nothing for you. It is good to find and have an exchange of ideas with the relevant persons among them."

I1: “...Our angels involved in all the contests and invitations we should participate... They were intensively interested in the networking part of these activities and motivated us by saying that you will certainly get a prize if you participate to the contest or this activity brings you many positive things. They took the whole burden from my back."

I6: "...When you go to the events which the business angels participate, you meet with the persons around them in case you are close to them during the organization."

I4: "You can reach the persons which you cannot through business angels."

I8: "There is no logic to go to large firms in the international part of the work, everything goes completely online."

I1: “...You tell the business angels that I should reach movie-makers and production companies. They find out all the contacts for you."

I7: “...I established my network by myself. I met with them by means of an organization ... I generally use this organization when I need to reach somebody. Therefore, the business angel did not make any significant contribution about networking."

I10: “...We indeed did networking for business angel...The business angel did not make any contributions about networking."

Our findings indicated that the business angels made limited contribution about contact with suppliers. However, they can make contributions with the suppliers such as law office and independent accountants who the business angel already benefits and the suppliers in the sectors which he knows and institutional suppliers. But the business angels can make no contributions about foreign suppliers and noninstitutionalized suppliers.

I7: "...He knows nearly all the employers in his city and helped us there... His gat an appointment from each one." 
I1: “...We are generally interested with our suppliers."

I5: "I can say that the business angel made no contribution in specific to our work."

I3: “...The places we provide supply are generally artisan style... medium-sized and small producers. Of course the probability which our business angels know these suppliers is quite law. In this respect we do not benefit from them."

I4: “...They did not make significant help about suppliers... Our suppliers are generally market people... They tried to help us once or time, but we did not get efficient results."

\subsubsection{Contribution of the Business Angels at the Field of Marketing}

First, we asked the entrepreneurs whether the business angels make any contributions in preparation of marketing plans. They stated that they generally gave only suggestions.

I3: “...Let's say angel investor who manages similar firms... For example you run an advertising campaign and they can share their experiences with us, if they did something about advertising campaign in the past and this sharing may be useful."

I2: “...We consult with the business angels about campaigns... We share our plans with them; in turn they convey their opinions... It is a nice thing for us to benefit from their experiences."

I6: “...We rarely get suggestions from the business angels about marketing, sales operations.”

Marketing research is not a common method which the entrepreneurs use. The firms have not made marketing researches, because they have not reached sufficient scale. Only one firm among our firms works with professional firm of marketing research.

I2: "If marketing research is implemented... we deal with a firm."

I3: “... We do not make marketing research as a start-up firm... We have some feeling about that issue... It is generally based on our feeling ... Our situation is a little based on observation and a little from data... We do not implement marketing research."

Business angels generally give suggestions about development of products and services after concretizing of new product and service proposals. Some business angels make no contributions in stage-gate process.

I1: "Always since he previously buys similar products which we try to produce and he sees its construction models... we tell him we will make some sort of a mouse and sell him technology shops, in turn he says that you should combine the mouse with keyboard and computer and then sell technology shops, but become a position to sell the product in these markets. ... They can expand the scope of the product."

I4: "They find the chance to come to some events and fairs we participate. They try our."

I5: "... Only the investors using our services make suggestions such as "If you had done this so, that would have been better" There is nothing more."

I6: "We develop common ideas. They motivate us and maybe contribute to us to reach that idea."

I3: "We get feedback from the business angels about design and use of web site, products sold through the web site and level of service."

I9: "They examine and give feedback to us, when we come to realize the visions which we previously talked and were of the same idea related to the product. But this rarely happens."

Pricing is another field which the entrepreneurs receive support from the business angels. The entrepreneurs benefit from the business angels about the pricing, discounts and establishment of differential pricing choices.

I8: "Their offer... there may be a basic part of work which the small, medium and large sized companies can register. Also there may be a premium service which can be sold expensively. We determined our package in this stated way."

I4:“...I can say that we determine... We only get suggestions from business angels ... Should we raise the prices? Are our prices low? ... We get suggestions about these issues... But we mainly determine the prices."

I2: "...Sometimes we are checking ideas with them."

I6: "We are rarely speaking... What do you think about our price increase from a lira to b lira? He said "good luck with it." 
I5: "Absolutely us... They do not intervene in us about that topic; even they do not make any suggestions... They leave pricing to us, because we know market and work better."

The business angels give us promotion support especially in the field of public relations. Also they support the entrepreneurs when and where the promotion activity will be carried out and what kind of costs they probably meet. Only one entrepreneur stated that he did not receive any promotion support from his angel investor.

I1: “...They contributed to us much... they drag the media behind us, whenever we develop interesting things... They have connections in very effective media channels. Somebody comes to your door to interview, when they call and say that our children develop a kind of thing."

I3: "They support us from introducing to public relations firm to sharing their ideas with us about use of advertising environment."

I7: "We have the business angel say that our firm has been the best investment... Tell our firm name and say that this firm is very successful, so constantly there will be a positive air around us... Therefore, firms which are working with us and firms which would like to work with us hear these expressions and we will remain in their mind when we run a business together. We have them say this."

I4: "They indeed contributed to us much in terms of public relations. They always talk about us with their interviews and speeches ... Thus they are very useful in making our name."

Furthermore, business angels contributed to the entrepreneurs in the field of sales by sharing their networks with us and getting an appointment from the customers on behalf of the entrepreneur and arranging interviews. Even in one case the business angel made sales for the entrepreneur. However four entrepreneurs said that they did not receive any contribution from the business angel in this field.

I1: “...The business angels themselves went to interview as if they were owners of the firm, when required."

I7: “...The business angels gave a well-known image to our firm, while we were making sales to our customers. It led a feeling of confidence and it was impactful in establishment of confidence feeling."

I5: “...They enable us to take new businesses by introducing us to their friends."

The entrepreneurs said that they did not receive sufficient support from the business angels about industrial information and competition analysis. Only one entrepreneur said that he received support about competition analysis, while four entrepreneurs said that they received support about industrial information."

I3: "Everything is happening... competitor recognition, their information about our competitors... but this is not so intensive."

I4: "A firm in our style... Firstly we established the firm which makes products integrated with social media. Naturally we are opening the way. In this respect, the business angels do not make contributions to us very much. A few more firms using our model were emerged. We re regularly searching... What we do and which way we turn. We conduct the research completely within ourselves."

\subsubsection{Contribution of the Business Angels at the Fields of Accounting and Finance}

The entrepreneurs stated that the business angels made significant contributions at the field of finance such as preparation and interpretation of financial statements and identification of important data and performance assessment. Furthermore, the business angels contributed to the about adaptation to the accounting standards.

I9: “...You have difficulty to self-evaluate how our firm should grow, we find ourselves as successful or unsuccessful in case how our firm grows... Your angel investors mostly know the figures of the other firms. They do not need to share with you, but at least they can set targets for you... As a result you are in the same boat. You want to implement the suggestions by your business angel."

I3: “...The essence of the matter is that no employees of the firm looks happiness index, everybody look the financial figures... Therefore, the business angels put support to us about financial issues."

I1: "...Many people look at revenue in the market.... They always remind us that your revenue is important. You are a high-tech firm. Your profitability is important... They have had us focus on profitability."

I4: “...They inform us how to do. We did not know what balance sheet, income statement were and meant for the firm one year ago... But now... they contribute us to develop ourselves about interpretation and meaning of financial statements, under which conditions we are in a bad or good position."

I8: "We talked about the importance of collection for a long time. You make out an invoice, but let's collect... 
Very basic but things that a foreign can avoid...Sales and marketing are learned on the way, but financial part requires a little information. We tried to learn finance from business angels."

I8: "We are presenting a reporting month... We are really working closely there. Sometimes tension may raise in negative reports."

I5: “...The business angels get in touch with our accountant very closely... Moreover they are looking a few issues. Opex ... cash flows etc..."

I10: "Our business angel also supported us very much in the field of accounting... Adaptation to the accounting standards, faultlessly."

\subsubsection{Impact of Contribution of the Business Angels on the Success and Growth of the Business}

The entrepreneurs said that the business angels made significant contributions about success and growth of the business. The business angels generally could accelerate the growth process with their investments. They also contributed to the institutionalization process of the firm.

I10: "Our business angel made significant contributions... But our venture did not tick along... We should have been more flexible and agile."

I2: “...We should have made significant amount of expenditures to expand our business... This angel investment enabled us to expand our business faster."

I4: "...They had much impact on our firm growth rather than its success... We reached a certain level about revenue... We could expand our business faster with their contribution."

I6: “...Our venture transformed from grocery to super market by virtue of the business angels.... They undoubtedly made unbelievable contributions in the growth of business, establishment of organizational structure, increasing of revenue."

I7: “...30\% of our growth was realized by angel investment... $70 \%$ by our sectoral information and our being very good... We gained because we had power to survive for a long time with our accumulation of knowledge..."

19: "...Our firm would not have been, if we have not had our first business angels... On the other hand our firm would have been in the half size of current firm size, if we have not had our second business angels."

\section{Conclusion}

We investigated the contributions of the business angels to the investees in the areas of management, marketing and financing and accounting during the post-investment process by interviewing with the entrepreneurs who took financial support from the business angels in establishment phases of their companies by using in-depth face-to-face interviews and telephone interviews from the perspectives of the investee companies. We found that the business angels made significant contributions especially in the fields of human resources management, networking, marketing and financing during post investment period.

All the entrepreneurs benefited from the experiences of business angels in the field of human resources management. Business angels made contributions about determination of absent positions in the firm, job advertisements, staff transfer, qualified personnel procurement, employment interviewing, employee/boss relations, preparation of business contracts, determination of wages, empowerment of employees, motivation and job satisfaction of employees etc. Furthermore business angels play a fundamental role in realization of business ideas, revision of business models and institutionalization of the firms. Networking was another area that entrepreneurs received significant contributions from their angels. On the other hand the post-investment contributions of the business angels in the field of marketing were generally about public relations, pricing, service development, preparation of marketing plan sales. Moreover, the entrepreneurs also probably benefit from the business angels about media planning, sectoral information, competition analysis, chain of distribution, export counseling and product development.

Business angels also made significant contributions to ventures in the field of finance. In this regard, they gave support to the entrepreneurs in monitoring financial performance, adaptation to accounting standards and preparation of financial statements, setting financial goals, focus on profit, arrangement of collection and expenditures. Finally the post-investment contributions of business angels raised the success probability of venture and accelerated its growth.

Consequently our findings indicated that business angels did provide not only financing for the ventures especially in the early stage of their development, but also made significant contributions especially in the fields of management, 
networking and marketing. So policymakers should create an environment which raises new business angels to emerge considering the role of ventures for overall economy. Further empirical studies can be conducted to determine how the entrepreneurs can get the maximum efficient benefit from business angels during post-investment.

We met three constraints during the study. First constraint is about data collection method and sample size. Our data was obtained from 10 entrepreneurs with face-to-face interview method and internet relay chat. The second constraint of the study was that it included the entrepreneurs from Turkey. The last constraint of the study was that it only included the entrepreneurs who got angel investing. Further empirical studies can be conducted to determine the post-investment contributions of the business angels in detail through quantitative research with more entrepreneurs who get or do not get angel investing.

\section{References}

Amatucci, A., Cardozo, R. N., Tune, K., \& Reinach, J. (2002). The role of angel investors in the assembly of non-financial resources to new ventures: Conceptual frameworks and empirical evidence. Journal of Enterprising Culture, 10(1), 39-65. http://dx.doi.org/10.1142/S021849580200013X

Amatucci, F. M., \& Sohl, J. E. (2004). Women entrepreneurs securing business angels financing: Tales from the field. Venture Capital, 6(2/3), 181-196. http://dx.doi.org/10.1080/1369106042000223579

Brettel, M. (2003). Business angels in Germany: A research note. Venture Capital, 5(3), 251-268. http://dx.doi.org/10.1080/1369106032000122095

Ehrlich, S. B., De Noble, A. F., Moore, T., \& Weaver, R. R. (1994). After the cash arrives: A comparative study of venture capital and private investor involvement in entrepreneurial firms. Journal of Business Venturing, 9, 67-82. http://dx.doi.org/10.1016/0883-9026(94)90027-2

Harrison, R. T., \& Mason, C. M. (1992). The roles of investors in entrepreneurial companies: A comparison of informal investors and venture capitalists. In N.C. Churchill, S. Birley, W.D. Bygrave, D.F. Muzyka, C. Wahlbin and W.E. Wetzel (Eds.), Frontiers of entrepreneurship research (pp. 388-404). Wellesley, MA: Babson College. Retrieved from http://hdl.handle.net/10068/440463

Karabayır, M. E., Gülşen, A. Z., Çifci, S., \& Muzaffar, H. (2012). Melek yatırımcıların yatırım kararlarında girişimci odaklılığın rolü: Türkiye'deki melek yatırımcılar üzerine bir çalışma. Ankara Üniversitesi SBF Dergisi, 67(02), 069-093. http://dx.doi.org/10.1501/SBFder_0000002247

Lumme, A., Mason, C., \& Suomi, M. (1998). Informal venture capital: Investors, investments and policy issues in Finland. Dortrecht, NL: Kluwer.

Macht, S. A., \& Robinson, J. (2009). Do business angels benefit their investee companies? International Journal of Entrepreneurial Behavior \& Research, 15(2), 187-208. http://dx.doi.org/10.1108/13552550910944575

Mason, C. M., \& Harrison, R. T. (1996). Informal venture capital: A study of the investment process, the post-investment experience and investment performance. Entrepreneurship and Regional Development, 8, 105-126. http://dx.doi.org/10.1080/08985629600000007

METUTECHBAN. (2016). Retrieved from http://metutechban.odtuteknokent.com.tr/Portal/Content/14

Paul, S., Whittam, G., \& Johnston, J. B. (2003). The operation of the informal venture capital market in Scotland. Venture Capital, 5(4), 313-335. 335, http://dx.doi.org/10.1080/1369106032000141931

Politis, D. (2008). Business angels and value added: what do we know and where do we go? Venture Capital, 10(2), 127-147. http://dx.doi.org/10.1080/13691060801946147

Sætre, A. (2003). Entrepreneurial perspectives on informal venture capital. Venture Capital, 5(1), 71-94. http://dx.doi.org/10.1080/1369106032000062731

Sørheim, R. (2005). The pre-investment behaviour of business angels: A social capital approach. Venture Capital, 5(4), 337-364. http://dx.doi.org/10.1080/1369106032000152443

Stevenson, H., \& Coveney, P. (1996). A survey of business angels: Fallacies corrected and six distinct types of angel identified. In R. Blackburn, and P. Jennings (Eds.), Small firms: Contributions to economic regeneration (pp. 37-48). London: Paul Chapman. http://dx.doi.org/10.1177/0266242697161006

Tashiro, Y. (1999). Business angels in Japan. Venture Capital, 1(3), 259-273. http://dx.doi.org/10.1080/136910699295893

$\begin{array}{llllll}\text { Under Secretariat } & \text { of } & \text { Treasury. } & \text { (2016) }\end{array}$ https://www.hazine.gov.tr/tr-TR/Rapor-Sunum-Sayfasi?mid=250\&cid=30\&nm=45\# 


\section{Interview Form}

\section{Categorical Questions}

Gender:

Age:

Level of education and department:

Business experience:

Business segment:

Number of employees:

Number of business partners:

Establishment date of business:

Partnership date with business angel:

Which stage did the entrepreneur get into a partnership with the business angel?

Partnership interest of the business angel:

Did business angels have majority vote?

To what extent did business angels participate to the board of directors, firm councils (advisory committee, supervisory board etc.) and did they have right to vote?

Did the business angel have any privileges in the firm?

How often did you meet with the business angel? Which issues did you discuss with the business angels? What situations did you meet with the business angel?

\section{Now could you give us detailed information on the following questions about management, marketing, financing and accounting?}

\section{Management:}

a. What kind of contributions did the business angel make in materializing your business idea?

b. What kind of contributions did the business angel make in developing your entrepreneurial abilities?

c. What contributions did the business angel make in forming your business model?

d. Did the business angel improve the management abilities of the business?

e. What kind of contributions did the business angel provide about networking?

f. What kind of contributions did the business angel provide in contacting with the suppliers?

g. What kind of contributions did the business angel provide about human resources?

h. What kind of contributions did the business angel provide about research and development?

i. Did the business angel monitor and control your business and did the business angel provide any contributions from these activities?

j. Could you evaluate the contributions of the business angel about management?

\section{Marketing}

a. What kind of contributions did the business angel provide for forming the marketing plans?

b. What kind of contributions did the business angel provide for the marketing research?

c. What kind of contributions did the business angel provide for the development of products and services?

d. What kind of contributions did the business angel provide for forming the chains of distribution? 
e. What kind of contributions did the business angel provide for the pricing?

f. What kind of contributions did the business angel provide for the advertising?

g. What kinds of contributions did the business angel provide for the sales?

h. What kinds of contributions did the business angel provide for the industrial information?

i. What kinds of contributions did the business angel provide for the competitiveness analyses?

k. Could you evaluate the contributions of the business angel about marketing?

\section{Finance and accounting}

a. What kind of contributions did the business angel provide for monitoring the financial performance of the business?

b. What kind of suggestions did the business angel give about financing and accounting?

c. What kind of contributions did the business angel provide for the financing of the new projects?

d. Could you evaluate the contributions of the business angel about financing and accounting?

Is there anything else you would like to add? 